\title{
Interpretation of Figurative Implicature in Malay Film
}

\author{
Norhidayu Hasan, Zaitul Azma Zainon Hamzah, Nor Azuwan Yaakob and \\ Fazilah Husin
}

To Link this Article: http://dx.doi.org/10.6007/IJARBSS/v11-i12/11820

DOI:10.6007/IJARBSS/v11-i12/11820

Received: 12 October 2021, Revised: 16 November 2021, Accepted: 30 November 2021

Published Online: 09 December 2021

In-Text Citation: (Hasan et al., 2021)

To Cite this Article: Hasan, N., Hamzah, Z. A. Z., Yaakob, N. A., \& Husin, F. (2021). Interpretation of Figurative Implicature in Malay Film. International Journal of Academic Research in Business and Social Sciences, 11(12), $794-810$.

\section{Copyright: (c) 2021 The Author(s)}

Published by Human Resource Management Academic Research Society (www.hrmars.com)

This article is published under the Creative Commons Attribution (CC BY 4.0) license. Anyone may reproduce, distribute, translate and create derivative works of this article (for both commercial and non0-commercial purposes), subject to full attribution to the original publication and authors. The full terms of this license may be seen at: http://creativecommons.org/licences/by/4.0/legalcode

\section{Vol. 11, No. 12, 2021, Pg. $794-810$}

Full Terms \& Conditions of access and use can be found at http://hrmars.com/index.php/pages/detail/publication-ethics 


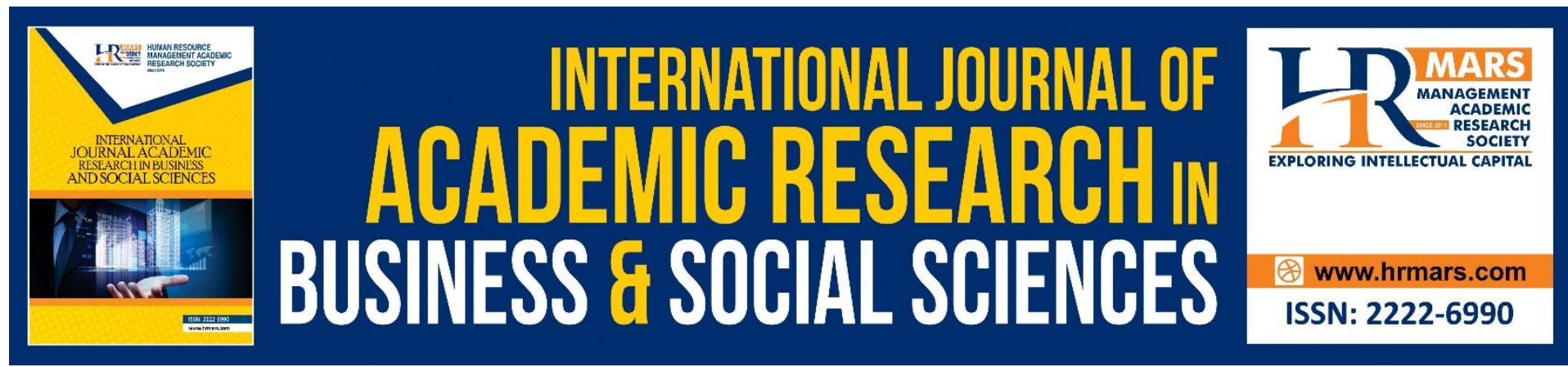

\title{
Interpretation of Figurative Implicature in Malay Film
}

\author{
Norhidayu Hasan, Zaitul Azma Zainon Hamzah, Nor Azuwan \\ Yaakob and Fazilah Husin
}

Department Of Malay Language Faculty of Modern Language and Communication, Universiti Putra Malaysia 43400 UPM Serdang Selangor, Malaysia

\begin{abstract}
Implicature can be described as an utterance that has a different meaning from what is presented by the speaker. There is implicature that uses figurative sentence by applying figurative elements, proverbs, metaphors and so forth. Interpretation of the figurative sentence implicature needs to be done by understanding the elements of the figurative or proverb that has been used. Malay community for example often uses figurative sentence implicature in the conversation. This is clearly illustrated in the art of Malay filmmaking that uses a number of figurative sentence implicature dialogue. This study aimed to analyze the meaning of figurative sentence implicature used in Malay films dialogue. A total of five Malay films that is Adnan (2000); Embun (2002); Paloh (2003); Malaya (2007) were selected for this study. The dialogue that is convenient with the objectives of the study were selected to be analyzed based on Relevance Theory. The selected films are qualified films as it was nominated and won the award in the Malaysian Film Festival, International Film Festival, and the Asia-Pacific Film Festival. The study found that there is a figurative sentence implicature in Malay films dialogue. The application of Relevance Theory for data analysis also highlighted the importance of context in understanding the figurative sentence implicature.
\end{abstract}

Keywords: Implicatures, Figuratives, Dialogue, Films, Malay

\section{Introduction}

Language is a tool that humans use to communicate with each other. Languages have certain formulas or rules that are clearly agreed upon by the users of a language. The definition of language itself has many meanings and views among language philosophers. But what is certain is that language is a tool used to communicate between human beings. Every society in the world has a different pattern of use or style of language when communicating with each other. Colored with the use of dialects according to the mixture of the spoken language. The Malay community is known for its refinement and the language tend to use speech containing two layers of meaning, metaphor or implicatures.

The Malay community often makes implicature speech as the basis for the delivery of a message to our listeners. Not limited to things that are quite harsh to the listener such as criticism, rebuke or satire but also extended its use to the delivery of words of praise and advice. The matter has been mentioned by Zainal, Musanif \& Mydin (2018), the height of the 
manners and customs that are owned by the community causing many ways of delivering criticism, sarcasm and also reprimand use indirect speech or metaphor. It is not too much to interpret one of the reasons for the use of implicatures which is to soften utterances that sound loud or impolite to the listener.

As is well known, the Malay community is rich with proverbs or figurative expression that uses symbolism. In everyday communication, for example, the community is also seen using figurative verse in their speech to deliver a speech. Such figurative sentences are sometimes used as the basis for implicature utterances in communication. To understand figurative type implicature utterances the listener needs to clearly understand the meaning of the proverb or find marker elements that can be used as a beginner's context. With a clear understanding of the meaning will help the listener interpret the implicature utterances of figurative sentences after being linked to the context of the conversation. According to Jalaluddin (1992), the implicature of a figurative sentence is an implicature that uses elements of allusion, parable, allusion, metaphor, irony and so on. Figurative sentence implicature is a form of implicature that uses metaphors and proverbs.

The use of implicatures is not only limited in everyday conversation or live conversation, but its use can be seen in film dialogue. Film is a form of communication media that uses audio visual aspects to convey a message in the form of neatly written stories and dialogues. Film is also a medium that communicates with the audience through the delivery of advice, reprimand, example of teaching and invites the audience towards a path agreed upon by the norms of society and religion. Film is not just an art but based on deep observation by a film production to create a situation that is imitated from real life. According to Mohamad (2015), a film has extraordinary power or influence because it has two tasks in one tool, namely as a medium of entertainment and as a vehicle to showcase culture, economy and politics through storylines drawn from real world experience or observation.

Overall, the film plays a role in depicting the life of a society. Thus, the dialogue adopted in the film is also an adaptation of the scriptwriter's observations of the actual conversational situation. The use of dialogue in a film is an important element of a film. The audio aspect is indeed understood by the production as well as the dialogue is the lead of the audio aspect in the film. The choice of words or expressions used in the dialogue is one thing that needs to be emphasized to make a film that has an impact on the audience. The use of dialogue that has a good flow of ideas will actually make the film rich in meaning. Turning to the assertion that the film is the result of an imitation of real life situations then the dialogue used is also the true color of the conversational situation.

Many Malay movies featuring implicature or figurative speech. According to Ahmad (2006) the thoughts or personality of a society can be highlighted through dialogue in the film shown. Even a film that uses implicature utterances is a quality film because it manages to convey an implicit message. Each dialogue used has its own meaning but dialogues that use implicature expressions need to be examined in more detail. The interpretation of the meaning of the utterance of the implicature of a figurative sentence cannot be done by looking at the literal meaning or the proverbial meaning used in the utterance alone, instead it needs to be looked at the context of the conversation

\section{Previous Studies}

Rahim \& Hamzah (2008) has disclosed how figures become treasure or gem in the Malay language. According to Rahim \& Hamzah (2008) each race has a different pattern or way of using language. It does not matter in direct utterance or indirect utterance. The community 
can be described as a community that values the importance of reason and wisdom in life. Every speech needs to be refined in its delivery but not in its message which needs to be clear and precise. Word order errors during communication cause a person to be labeled as impolite or rude. When examined metaphor that has long existed as a proverb that is always relevant all time is the result of observation of the Malay community which is creative and critical. They take an example by observing the situation around and make the experience as a major source for the metaphor is a vivid example of the wisdom of the community. Matching one thing with another accurately is a process that involves a high level of understanding of meaning.

Furthermore, in the study of Mohamad \& Hamzah (2015) mentioned that implicature is a form of metaphor that is used to explain or convey a message but does not use actual utterances. In a simple sense it conveys a different meaning than the literal meaning of utterance. The use of implicatures is not only limited in creative works or two -way communication but also in one -way communication such as talks. The speaker applies the element of implicature in the lecture delivered as a medium to convey the essence of the explanation of the faith. The use of implicatures is seen to strengthen the delivery of meaning by manipulating language based on the context shared between the speaker and the listener. The delivery of a clear meaning or message can strengthen trust and attract the audience's interest in the content of the talk. Even implicature is a medium that can make it easier for the speaker to explain something that is difficult to explain literally or reveal the message as best as possible. Good language processing can influence a person's thoughts and beliefs.

Ahmad \& Jalaluddin (2013) have first touched on the subject of language manipulation being able to influence one's opinions, views and thoughts. The use of implicatures is a way for a speaker to manipulate a person's thoughts and opinions. Ahmad \& Jalaluddin (2013) took the example of a question and answer session in court to explain how implicatures are used by advocates to cast doubt on the testimony of witnesses. Advocates as speakers in this situation wisely use implicatures to trap witnesses or cast doubt on the testimony of witnesses of the incident. The findings of Ahmad \& Jalaluddin (2013) also clearly show that the answers or testimony of witnesses will change if asked with different forms of questions or implicature expressions even though each question contains the same meaning.

The study of Ghani \& Azman (2008) is one example of the existence of implicatures not limited to direct communication only but also applied in fiction. The study of Ismail \& Mat (2008) argued that in a work of fiction, the author tries to process the language well and carefully to ensure the delivery of a clear message. The use of implicatures or allusions in writing is usually a reflection of the sharpness of the author's critical thinking in manipulating language to convey something that is advisory or satirical. A wise work of fiction is produced by a wise author and reader. Layered language in a work of fiction will make the reader "wise" when the reader tries to interpret the true meaning of the author. The use of implicatures not only beautifies the language of fiction but also serves to support the burden in conveying a message that cannot be processed based on the literal meaning of utterances.

\section{Methodology}

This study is a qualitative study using data analysis methods. Selection data is based on the movie dialogue Malay film (Embun, 2002; Adnan, 2000; Hati Malaya, 2007; Paloh, 2003). The selected films were watched and the dialogue used was scrutinized. After each dialogue in the film is examined, the appropriate dialogue is screened to be used as research data. The results of the study found that there were 5 implicature utterances of figurative sentences 
used in the film. The main reason for the selection of the 5 data is because it coincides with the objectives of the study. The selected dialogues were transcribed in transcript form and analyzed based on Relevance Theory.

\section{Relevance Theory}

Relevance theory is a theory in the field of pragmatics put forward by Sperber and Wilson (1986) that emphasizes the concept in utterance, understanding of meaning will not be achieved if only examining the literal meaning of words used yet it should also be analysed based on context. According to Sperber and Wilson (2012) any uttered utterance that does not carry a literal meaning can be classified as implicature. In utterance the speaker will endeavour to give sufficient inference to the listener. The main task of the listener is to utilize this inference along with the listener's existing knowledge to decipher the speaker's meaning and is driven by the listener's initial expectations of the meaning of the speaker's utterance. The following is an explanation of the three main concepts of Relevance Theory.

1. Context

Context is a set of premises used during the process of utterance interpretation. Sperber and Wilson (1986) explain context is an assumption about a psychologically constructed world. The context in this case is not limited to information about the immediate physical environment or about the future, scientific hypotheses or religious beliefs, beautiful memories, general cultural assumptions and beliefs about the mental state of the speaker, perhaps all of these play a role in interpretation (Sperber \& Wilson, 1986).

2. Contextual Effects

According to Sperber and Wilson (1986), contextual effects involve two important features of utterance comprehension namely comprehension involves the sharing of knowledge together for a set of assumptions and several assumptions seen as new information being processed in the same context. The effect of context is the initial assumption that the listener has. When a utterance is presented by a speaker, the listener's task is to either combine or reinforce, or drop the context presented by the speaker with existing initial assumptions in order to produce a contextual effect. The effect of context is the result of the correlation between new information and old as a premise. In short, the premise of an assumption that has no contextual effect in a given context is irrelevant in that context. (Jalaluddin, 1992: 34)

3. Processing effort

Processing effort involves the effort of interpretation of meaning by those involved in a conversation. According to Wilson \& Sperber (1998: 9), processing effort involves utterance comprehension that depends on two main factors namely the form of utterance used and the cognitive effort involved in shaping the appropriate context. In short in Relevance Theory, the greater the processing effort the lower the relevance of the utterance. 


\section{Discussion and Analysis}

Data 1

Table 1. Figurative Implicature 1

Samad $\quad$ Payah Embun, kaki tangan kami semua terikat. Dua tiga hari
sekali Jepun mai periksa kami. Kami pi mana, duk mana, buat
apa.
It is hard, Embun, our hands and legs are all tied up. Once in
every two or three days they will check on us. Where we go,
where we at or what we do.
Embun $\quad$ :
Ka ni lagu mana? Boleh ka tak boleh
So how is it now? Can or not?
$:$ Aku tak berani. Terang-terang depa nampak kita tunjuk
perasaan kelmarin. La ni nak buat muka selamba ja nak mintak
tolong lepaskan Bayu. Silap hari bulan dengan kita-kita semua
kena angkut baru hampa semua tau
I don't have the courage. We can clearly see that they saw us
protesting last time. Then we have the guts to ask them to
release Bayu. Later it is not just me, maybe all of us will be
caught up, too.
Embun tak paksa. Tak pa lah. Tau la Embun nak buat lagu mana
Embun $\quad$ I am not forcing. It is okay. I know what to do.

The following table is an explanation of the literal meaning of the implied data 1 utterances as shown in Table 2:

Table 2: The Literal Meaning Of Figurative Implicature 1

\begin{tabular}{|l|l|l|}
\hline Data & Implicature & Literal Meaning \\
\hline 1 & It is hard, Embun, our hands and legs & $\begin{array}{l}\text { Hard-complicated, not easy, difficult } \\
\text { are all tied up. }\end{array}$ \\
& & $\begin{array}{l}\text { Legs- body parts from thigh to feet } \\
\text { Hands- body parts from shoulder to } \\
\text { fingertips. } \\
\end{array}$ \\
& & Our- us \\
& All-all of us \\
& Tied - bound \\
\hline
\end{tabular}

In order to describe the implicature that uses the element of comparison or allusion to a thing or topic that can be seen, the thing or topic must first be explained the meaning, characteristics or conditions because it can be a trigger or idea originating to the interpretation of the meaning of the implicature. Through the implicature utterance of data 1 above, the utterance can be classified as the implicature utterance of a figurative sentence or metaphor that is an utterance that uses symbolic elements. The phrase "It is hard, Embun, our hands and legs are all tied up." is seen using the word "tied" as the main context in describing the meaning of this statement. Based on the literal meanings explained in Table 2, the description of the literal meanings for data utterance 1 is meant to be tied to something such as a thread or rope. When an object, person or animal is tied up it is certain that any movement or act of moving becomes difficult. In short it is something movement will be hindered. However, if we take the literal meaning of the utterance alone without regard to the context, the utterance does not carry the true meaning intended by the speaker. 
Therefore, the explanation of the implicature utterance of data 1 should be done by explaining the symbolism of the word "tied" first and then linked to the utterance context to form the effect of the context or the conclusion of the relevant implicature.

The background of the context of this utterance is that the speaker (Samad) and the listener (Embun) are discussing to release the listener's brother, Bayu, who has been arrested and detained by the Japanese. With knowledge of the context of the matter discussed, the listener knows that the utterance of data 1 does not refer to the literal meaning or actual state of the speaker's body being tied with thread or rope because the listener is indeed seeing and aware of the speaker's untied condition. Therefore the initial assumption that the speaker is being tied with a rope or thread can be dropped. The speaker is seen to have provided adequate beginner context by using the word "bound" which can help the listener decipher the meaning of the implicature with the help of encyclopaedic notes. Listener encyclopaedic notes can be a good beginner context to help listeners interpret the implicature utterances of data 1.

Listeners can utilize or use encyclopaedic notes on the word "bound" to form some premicature or implicature assumption. Relevance theory emphasizes that any word that has been used in a previous conversation can be the context for an ongoing conversation. The words used will be stored in human memory which in turn can be an inference to the understanding of implicature utterances. Based on the encyclopedia, the listener knows that a "bound" state will cause an act or behaviour to be restricted or obstructed. The listener's understanding of what is said to be "bound" will lead to the existence of relevant implicature assumptions.

According to Jalaluddin (2003) in Theory of Relevance, context can make the understanding of the meaning of utterances occur more easily. The context of the speaker's experiences or memories can help to understand the implicature. Speakers and listeners shared the experience of seeing a listener brother arrested by the Japanese as a result of being involved in a movement against the Japanese. The shared knowledge of the consequences of opposing Japan shared by the listener and the speaker will ensure that the interpretation of the information by the listener is exactly as intended by the speaker.

Every detail of the contextual information used in interpreting utterances must not only be known to the speaker and the listener, but both already know it (Sperber \& Wilson, 1999: 30). Therefore, this knowledge sharing will form conclusions relevant to this implicature. In short, the sharing of knowledge between the speaker and the listener on the actions and punishments imposed on individuals who oppose the Japanese will assist in the interpretation of the implicature. Based on the context, the premise that can be produced is as follows:

\section{Premise 1) Movement is controlled \\ 2) Eyed by the Japanese \\ 3) Fighting the Japanese is a mistake \\ 4) The speaker is scared to be caught}

Based on the premise of the resulting assumptions, the implicature conclusion that can be formed is "the speaker cannot help the listener". This conclusion is relevant because it can be combined with the new information given by the speaker in the subsequent speech that is "Once in every two or three days they will check on us. Where we go, where we at or what we do". In Relevance Theory there is an ad-hoc concept that communication participants are allowed to get additional information from previous or subsequent utterances. This ad-hoc concept will make it easier for the listener to find appropriate references to interpret the 
meaning of the utterance. In the utterance that came after that "Once in every two or three days they will check on us. Where we go, where we at or what we do" contains a reference to the utterance of the implicature. As a result, the implicature utterance is easily processed because the speaker provides a reference to the utterance after that.

This new utterance contains information that can strengthen the meaning of the word "bound" in this implicature utterance is that all the actions of the speaker are observed by the Japanese and the speaker can be arrested if committing an act that is considered wrong to the Japanese. The listener can associate the word "bound" with the utterance that is present afterwards to further strengthen the implicature assumption. Thus the effort to process the utterance becomes simple in turn making the implicature utterance relevant.

It has become the culture of the Malays where the use of words or phrases allegorical is considered more polite to refuse a request or invitation. Therefore the use of implicatures data 1 is viewed in context and confidence of the Malays who practice on taking care of the listener's feeling when conveying a message. The effort to process this utterance is also easy because the listener gives immediate feedback by asking the willingness of another character to help the listener after hearing the implicature utterance. The listener is seen to understand the rejection made by the speaker. The effort to process this utterance is easy because the speaker has given the appropriate context to the reader by using the word "bound" which is the word that has been stored in the encyclopedia of the reader. The use of data implicature 1 in the dialogue above is as an effort of the speaker to keep the heart of the listener. The speaker does not state directly about the speaker not wanting to help the listener. This is because to avoid offending the listener and to be able to maintain the dignity of the speaker.

\section{Data 2}

In addition to implicature utterances that use symbolic allusions there are also implicatures that use proverbial expressions in implicature utterances. An example of the use of the proverb type implicature is as in the saying "men are really good at planting sugarcane on the edge of the lips". The use of these implications can be traced in the following dialogues in Table 3:

\section{Table 3. Figurative Implicature 2}

Adnan : Lega rasanya, ingatkan Safi tak nak jumpa abang lagi I feel relieved, I thought you don't want to see me anymore

Safi : Entah-entah abang yang tak nak jumpa Safi. Maklumlah baru pulang dari perantauan. Dah puas tengok dewi-dewi jelita di negara orang

Or maybe it's you who don't want to see me again. Well you just came back from travelling. Perhaps you have seen other pretty ladies in other lands.

Adnan : Memang ramai dewi-dewi jelita di sana, tapi tak sama dengan gadis di Sungai Ramal ni There are many pretty ladies there but it is not the same with a lady here in Sungai Ramal.

Safi : Orang lelaki memang pandai menanam tebu di tepi bibir. Men are really good at planting sugarcane on the edge of the lips 
If interpreted through the meaning of the proverb alone without relating to the context of the utterance the result of the message or thing that the speaker wants to convey is less accurate. To explain the implicature of figurative sentences using proverbs, the interpretation of meaning needs to be done by examining the meaning of the proverb first and then relating it to the context to get the true meaning of the utterance. A proverb is a sentence or group of words that has a fixed order and contains a specific meaning. According to Hassan \& Hamzah (2010), the proverb is a kind of style that is born of the minds of the Malays who are concerned with manners and politeness when conveying a message or instruction. Besides, Wahab \& Kamil (2012) explains that proverbs are a language that has elements of modesty and beauty of diction and used by the community to express feelings, thoughts or messages. If the proverb in the utterance is detailed in literal meaning the following is a description of its meaning as shown in Table 4:

Table 4: The Literal Meaning Of Figurative Implicature 2

\begin{tabular}{|l|l|l|}
\hline Data & Implicature & Literal Meaning \\
\hline 2 & Men are really good at planting & Men - male \\
sugarcane on the edge of the lips & Really- actually, truly \\
Good- clever, skillful \\
Planting- fill the seeds into the ground \\
Sugarcane- a plant that produce sugar \\
& & $\begin{array}{l}\text { On- a preposition } \\
\text { The edge- side } \\
\text { Lips- mouth }\end{array}$ \\
&
\end{tabular}

Based on the description of the literal meaning or literal meaning of the proverb must not be able to explain the meaning of the implicature of data 2. However, the use of this proverb is indeed an antecedent to the conclusion of implicature. Relevance theory suggests a way of expanding the context by adding encyclopaedic entries to it (Sperber \& Wilson, 1999: 245). Based on this statement, the listener's encyclopaedic record of the true meaning of the proverb can be a starting point for forming an implicature premise. The listener knows that the phrase "planting sugarcane on the edge of the lips" does not refer to the literal meaning of the sentence but to the figurative meaning. Sugarcane is a plant that is very synonymous and associated with sweet taste. The listener has knowledge and encyclopaedic notes on the meaning of the proverb "planting sugarcane on the edge of the lips" means the act of uttering sweet words to persuade, take heart, just praise and so on.

As explained earlier, the listener must first understand the meaning of the proverb and then relate it to the context to obtain the true meaning of the implicature of data 2 . This is in line with the statement of Jalaluddin (1992), to understand the proverbial implicature, the meaning of the proverb is necessary understood first then the meaning of the implicature can be interpreted. Apart from that, the statement that was present before that "There are many pretty ladies there but it is not the same with a lady here in Sungai Ramal." can be used as a reference for the listener. The speaker (Safi) knows that the listener (Adnan) praises the beauty of the lady in Sungai Ramal which is unmatched by other ladies. The speaker is aware and aware of the issue of their trial is the listener trying to persuade the speaker by praising the beauty of the speaker and this is reciprocated with implicature utterances by the speaker. Based on the utterance, the listener can make inferences that can explain the true meaning of the implicature. The premise that can be formed is as follows: 
Premis 1) the listeners saying is just to praise the speaker

2) the sayings are not sincere

3) sayings that just to take care of one's feelings

Based on the premicature assumption formed, the implicature conclusion that can be made based on the implicature statement of data 2 "men are good at planting sugarcane on the edge of the lips" is "the speaker does not believe in the words of praise expressed by the listener". Even if the speaker does not state the utterance directly, the listener can still understand the real meaning that the speaker wants to convey with the help of the context that has been supplied by the speaker. This implicature conclusion is also relevant to the cultural context of the speaker and listener. Speakers and listeners is the Malay nation known for its use of proverbs or figurative. In Relevance Theory the sharing of culture and language can contribute to the formation of common inferences (Sperber \& Wilson, 1999). This cultural sharing thus facilitates the understanding of the implicature of the proverbial form.

The context of the event also contributes to the implicature conclusion. Based on the context of the incident, the listener went to the United States to undergo military training and left his lover, a speaker in the village of Sungai Ramal. The sharing of experiences between the speaker and the listener can provide a reference to the intention of this utterance being conveyed. The listener can understand that the speech delivered by the speaker is to show a feeling of discouragement or sulk because the listener left her. Although this implicature utterance uses two layers of interpretation that is the first to understand the meaning of the proverb and then to relate the meaning of the proverb to the context. The implicature is still easy to understand because the matter discussed is within the range of knowledge between the speaker and the listener. In addition the context of the speaker's relationship with the familiar listener causes the effect of the context to be produced with easy effort. The speaker's statement is relevant to the listener, which is why the listener responds quickly. This implicature conclusion has high validity because it relates to context. These implicature utterances are seen as making statements or expressing feelings.

\section{Data 3}

\section{Table 5. Figurative Implicature 3}

Mala : Tapi Mala mahu tahu secara ikhlas. Sekiranya kita tak sehaluan. Kau masih mahu aku?

But I want to know it sincerely. If we are not on the same path, do you still want me?

Zahari : Tak sehaluan? Not on the same path?

Mala : Jika Mala pilih perjuangan Tunku. Aku mahu bersama kau. Tapi hati Mala pilih merdeka

If I choose Tunku's plan, I want to stay with you. But my heart chose freedom.

Zahari : Mala, kau Malaya di hati aku. Kita akan tetap tuntut merdeka Mala, you are the Malaya in my heart. We are still going to demand for freedom.

Mala Hati aku untuk kau sejak pertama kali kita bertemu. My heart is for you since the first time that we met 
In the dialogue above the speaker uses the word "Malaya" as the main reference in the implicature utterance of the figurative sentence "Mala, you are Malaya in my heart". The use of this symbolism can be described as a metaphor. Metaphor is the use of words that contain different meanings than the actual meaning of the word. Sperber and Wilson explain the metaphor as follows:

Metaphors are the most obvious cases where the meaning conveyed

by use of word goes beyond the linguistically encoded sense

Sperber and Wilson (2012:16)

Therefore, the explanation of the implicature of data 3 needs to be done by examining the elements of the metaphor first and then linked to the context of the utterance. The following is the meaning of the implicature utterance of data 3 based on the literal meaning.

Table 6: The Literal Meaning of Figurative Implicature 3

\begin{tabular}{|l|l|l|}
\hline Data & Implicature & Literal Meaning \\
\hline 3 & you are the Malaya in my heart & $\begin{array}{l}\text { Malaya- the land of Malaya } \\
\text { In- a preposition } \\
\text { Heart- an organ in humans body } \\
\text { My- the pronoun to I }\end{array}$ \\
\hline
\end{tabular}

Explanation of meaning based on abstract or literal meaning alone will not be able to explain the meaning of utterance as intended by the speaker. Abstract meaning is the meaning of a word, phrase or sentence based on a dictionary. If the utterance is explained in terms of abstract meaning, the utterance carries the meaning that Mala is a country that is located in Zahari's heart. But the meaning is not the real meaning that the speaker wants to convey. The explanation of the meaning of this implicature should be done by examining what is said as "Malaya". The listener's encyclopaedic notes with what is said to be "Malaya" serve as a good beginner context. Listeners learn that Malaya or Malaya is the name for a countryborn of the speaker and listener.

The speaker has provided a good beginner context with the use of the word "Malaya" in the implicature of data 3 . The utterance of data 3 contains meanings that can be interpreted more accurately if guided by the context. As explained by Peccei (1999: 30), the explanation of the meaning of implicatures must be made based on the context of the utterance and the knowledge possessed by the communication participants. Appropriate context is very important in understanding implicative speech to avoid misunderstandings. The introductory context for this implicature statement can be developed through encyclopaedic notes with what is said to be "Malaya". The sharing of experiences between speakers and listeners who sought to liberate Malaya from foreign colonialism has provided a reference that Malaya is a country that is deeply loved and cherished by speakers and listeners. In addition, the context of speaker trust can also help explain the implicature statement of this data 3. In the passage above, the speaker is seen as an independence fighter and has chosen to support Dato Onn's ideology and struggle. Yet unlike the listeners who chose to support Tunku Abdul Rahman. Although the speakers and listeners differed, they still shared the same goal, which was to liberate Malaya. Based on the implicature, the premise that can be formed is as follows: 
Premise 1) Malaya is a country that is important and loved by Zahari

2) Mala is important to Zahari

3) Mala is loved by Zahari.

Relevance theory emphasizes on the use of context that matches the information in the utterance will be able to produce maximum contextual effect. Based on the context, the implicature conclusion for data statement 3 "Mala, you are Malaya in my heart" is "the speaker still loves the listener despite different beliefs". This conclusion can be strengthened by the statement that was present before that is "But I want to know it sincerely. If we are not on the same path, do you still want me? and "If I choose Tunku's plan, I want to stay with you. But my heart chose freedom". This statement can provide additional information that can be an inference that is the state of love of the speaker to the listener if different understandings. According to Clark (2013:224), in the utterance there is information that can be combined with the initial assumptions of the listener to produce a relevant and easily understood context.

Thus the assumption that "differences of opinion will not affect the love of the speaker" can be combined with the information found in the utterances that preceded it. Through such additional information, the resulting contextual effect is to state the state of their relationship if they choose a different ideology. This is also explained by Jalaluddin (2003: 50) in Relevance Theory, the context presented by the speaker can be strengthened with existing assumptions to produce the effect of context. The context used in this statement corresponds to the assumption of the listener's premise and this will allow for the resulting contextual effect. Interpretation of this speech requires little effort because the same information-sharing environment between the speakers and listeners recognize Malaya is important for the people of Malaya then. This can be explained by the statements of Sperber and Wilson (1998), in The Relevance Theory of processing efforts involving the form of the utterance and the effort required by the mind to interpret the actual utterance. Speech that is easily understood by the speaker thus shortens the effort time to process the meaning of the speech. Based on the dialogue above as well, the conversation between Mala and Zahari is about expressing Zahari's feelings of love for Mala even though they have different thoughts. Therefore, the intention of the speaker in this implicature utterance of data 3 is to express a sense of love and affection for Mala.

\section{Data 4}

\section{Table 7. Figurative Implicature 4}

Azman : Depa nak bagi kita merdeka? Pi lah. Aku dah bagi tahu hangpa silap bulan kita semua ni dah kena tipu bulat- bulat. Aku tak percaya dengan Jepun ni

They want to give us independence? Go ahead. I told you that this might be their trick to us. I don't trust these Japanese

Kadir : Man hang ni, cakap malam dengar-dengar, cakap siang pandang-pandang. Nanti tak pasal-pasal masuk dalam baru hang tau Man, listen when speaking at the night, look around when speaking in the daylight. Or else you'll be in. 
Based on the example of dialogue in Table 7 above, the implicature can be detected through the use of proverbs in the phrase "Man, listen when speaking at the night, look around when speaking in the daylight.". Although basically the proverb means "beware of your words". But there is an implicit meaning that needs to be conveyed behind the use of the proverb. The proverb used is the main reference to help interpret the meaning of this implicature. To explain the meaning of the figurative implicature, the meaning of the proverb needs to be linked to the context.

Table 8: The Literal Meaning of Figurative Implicature 4

\begin{tabular}{|l|l|l|}
\hline Data & Implicature & Literal Meaning \\
\hline 4 & $\begin{array}{l}\text { listen when speaking at the night, } \\
\text { look around when speaking in the } \\
\text { daylight }\end{array}$ & $\begin{array}{l}\text { Speak- uttering words } \\
\text { Night- the day after the sun sets } \\
\text { Listen- hear or catch sounds with the ears } \\
\text { Daylight- the day after sunrise } \\
\text { Look around- sight or looking with the eyes }\end{array}$ \\
\hline
\end{tabular}

Table 8 is an explanation of the meaning of data utterances 4 based on literal meanings. If the phrase "Man, listen when speaking at the night, look around when speaking in the daylight" is explained through a literal meaning without referring to the meaning of the proverb used in the statement, the meaning is still less accurate or cannot convey the meaning that the speaker wants to convey. The listener's knowledge of the meaning of the proverb "Man, listen when speaking at the night, look around when speaking in the daylight." can be a good beginner's context to explain this implicature. The listener knows that the true meaning of the proverb in the implicature utterance is to carry the meaning of "beware of your words".

By taking advantage of the encyclopaedia notes, the listener learns that the meaning of the proverb "listen when speaking at the night, look around when speaking in the daylight" means to be careful when speaking, especially things that are secret or confidential. The listener is able to relate the "secret matter" in the meaning of the proverb with the context of the knowledge of the matter discussed earlier which refers to the feeling of dissatisfaction with the Japanese. As explained in data 2 previously the listener must first explain the meaning of the proverb and then relate it to the context of the utterance in order to obtain the true meaning of the implicature utterance. The statement that was present before that was "They want to give us independence? Go ahead. I told you that this might be their trick to us. I don't trust these Japanese." can help the listener interpret the speech. In the speech, the listener has loudly expressed his dissatisfaction with the Japanese. This utterance is then answered with the implicature utterance of the speaker. The speakers and listeners were aware that the issue being discussed was a difficult issue i.e. an attempt to oppose the Japanese in order to gain independence. Based on the context of the premise statement that can be generated are as follows:

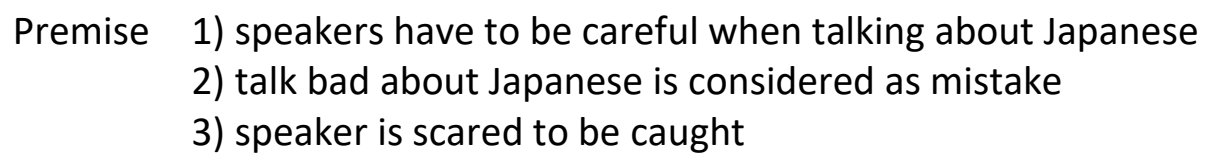

Based on the premise formed, the conclusion of the implicature utterance of the figurative sentence "listen when speaking at the night, look around when speaking in the 
daylight" means "the speaker forbids the listener to talk about Japan". This conclusion is relevant because it can be connected with the statement that came after that "Or else you'll be in.". The word "in" refers to the prison. The context of the speaker's and listener's knowledge of the prison sentences imposed on those who tried to oppose Japan can also be the main context of utterance interpretation. The context of the speaker's belief that the Japanese would punish anyone who dared to oppose them was a key inference for utterance interpretation. Speakers are worried if they will be arrested if they continue to talk out loud about Japan.

Basically, the proverb only explains or tells the listener to be careful when talking about something. Yet based on the context, the conclusion that can be drawn is that the speaker forbids the listener to talk about the matter for fear of being imprisoned. The use of the implicature "Man, listen when speaking at the night, look around when speaking in the daylight." clearly shows its primary function to prohibit the speaker from speaking further. The use of this implicature as prohibiting the act of the listener is relevant because it relates to the context of the relationship between the speaker and the listener. Speakers and listeners are friends who seek to liberate Malaya from the Japanese colonisation. Concerned of his friend's safety, the speaker used the implicature to prohibit the listener. The use of implicatures in the form of prohibition sounds more polite and the speaker is seen trying to take care of his friends' feelings.

\section{Data 5}

\section{Table 9. Figurative Implicature 5}

Ariffin Nur : Jangan salah tafsir ya. Saya ni miskin. Barangkali bodoh pula tu. Maklumlah sentiasa menolak rezeki. Tapi saya ada maruah. Tak sesetengah macam orang tu yang sanggup melupakan perjuangannya. Yang sanggup menyembah matahari.

Don't misinterpret me ya. I am poor and perhaps stupid too. Always pushing the rezeki. But I have dignity. Not like some of them who are willing to forget the hardship. Who is willing to worship the sun.

Ahmad : Itu boleh dimaafkan. Bukan?. Lagi pun kami bukannya sukasuka untuk menyembah matahari tu.

That can be forgiven, right? Besides we don't do it for fun to worship the sun.

Ariffin Nur : Bukan suka-suka nak sembah matahari?. Sedar tak kamu apa yang diamalkan British sama seperti yang diamalkan Jepun sekarang ini. Selama ini kamu menganggap kamu menentang British. Tiada bezanya. Apa yang diamalkan British sama dengan Jepun.

Worship sun is just for fun? Do you realize what has been practiced? Are you aware that what the British practice is the same as what Japan does now? All this time you thought you were against the British. There is no difference. What the British practiced was the same as the Japanese.

In data 5 the use of figurative sentence type impicatures can be detected in the utterance of "who is willing to worship the sun". The implicature utterance of this type of figurative 
sentence data 5 needs to be explained the meaning in literal terms first to help understanding the real meaning through the inference supplied by the speaker. Here is a description of the literal meaning of the data implicature statement 5 "who is willing to worship the sun".

Table 10: The Literal Meaning Of Figurative Implicature 5

\begin{tabular}{|l|l|l|}
\hline Data & Implicature & Literal Meaning \\
\hline 5 & Who is willing to worship the sun & $\begin{array}{l}\text { Willing- ready and want to do something } \\
\text { Worship- pay homage by saluting } \\
\text { Sun- the star that is the center in the solar } \\
\text { system that emits light and heat. }\end{array}$ \\
\hline
\end{tabular}

Based on the literal meaning as explained in Table 10 it means the listener pays homage by lifting worship to the star. However, this literal meaning only explains the meaning in layers and does not explain the real meaning that the speaker intended. "The one" in the above statement refers to the listener (Ahmad). Therefore, the use of "The one" is meant to explain Ahmad's actions or behaviour.

The literal meaning of a spoken sentence is not sufficient to encode what the speaker means; it only helps the speaker deduce what he or she means (Sperber \& Wilson, 1999: 47). Thus words such as "worship" and "sun" literally cannot explain the meaning of the speaker but can be the context to the production of implicature conclusions. Based on Sperber and Wilson's emphasis in Relevance Theory, the above statement contains words that can help the listener interpret the statement. To understand the implicature utterance of data 5 the words "worship" and "sun" become antecedents to refer to the true meaning of the speaker. These words are then linked to the context of the utterance to form an implicature conclusion. To understand this utterance, the listener's encyclopedic notes on "worship" and "sun" become a beginner's context to understanding the implicature of data 5. Speakers and listeners have knowledge of the act of "worship" which refers to acts of respect, glorification, submission and obedience. This listener's knowledge can be a beginner's context for understanding implicature utterances.

Moreover, the context of the listener's knowledge of the "sun" is also very important to understand the implicature utterance of data 5. The listener knows clearly that the "sun" is meaningless as a star that emits light and heat. This is because in the context of the utterance that is present afterwards, the speaker has supplied sufficient and relevant additional information to be an antecedent to the word "sun" in the utterance of the implicature. References to what is said to be the "sun" were provided by the speaker through the utterance that came after that "indeed we have to fight the Japanese" and "are you aware that what the British practice is the same as what Japan does now". Also, based on the context of the listener's knowledge, Japan is known as the country of the rising sun and the sun symbol is found on the official flag of Japan. Through the additional information in the utterances present afterwards and the context of the listener's knowledge, a conclusion about the true meaning of the sun is referring to the Japanese side can be produced by the listener.

However, this explanation is only as far as the explanation of the figurative meaning of the verse. The explanation of the utterance merely describes the listener's act of respecting the Japanese. To understand the implicature, the listener must look at other contexts as well. Another context for implicature utterances is the context of events. The speaker is someone who chooses to fight against the Japanese colonialism while the listener is someone who serves as a Japanese policeman. Although the speakers (Ariffin Nur) and the listener (s) are 
the people of Malaya but Ahmad chose to work with the Japanese occupation of Malaya, which was at the time. In Relevance Theory, the context of the relationship between the speaker and the listener who know each other can facilitate the understanding of the implicature utterance. There are several premises that can be formed based on that context.

\section{Premise 1) the act of the listener worshiping the sun \\ 2)submissive and obedient to the colonizers \\ 3) serve for colonizers}

In Relevance Theory, context does more than just isolate inaccurate interpretations; it provides a premise without which implicatures cannot be inferred directly (Sperber \& Wilson, 1999: 66). Based on the Relevance Theory, the resulting premise can give rise to the implicature conclusion of "listeners betray the nation". The conclusion of this implicature is relevant because it can be linked to the context of the utterance that was present before that which is "not some kind of person who is willing to forget his struggle". This speech is a reference to Ahmad, a people of Malaya who did not fight against the invaders. The word "struggle" in the context of the event refers to the act of trying to resist and repel the Japanese or the enemy of Malaya. The effect of the resulting context is relevant because it is in line with the statement that comes after that which is "we have to fight Japan. We must dare to fight for the liberation of our country ". The implicature conveyed is an allusion to the actions of the listeners who did not try to oppose the colonialists.

Although the use of this implicature is a figurative sentence, the effort to process the true meaning of the implicature is simple because there is information supplied in the utterance that can be combined with the listener's assumptions. Moreover, simple endeavors are influenced by common and parallel knowledge of the issues discussed. The resulting contextual effect is to serve to satirize the behavior and decisions of listeners who choose to serve with the Japanese police. Thus the real intention of the speaker in this implicature utterance is to question the authority and spirit of the listener's love for the homeland.

\section{Conclusion}

Although implicature utterances use proverbs or symbolic elements, the actual meaning of the speaker can be explained if linked to context. The processing effort is easy because the speaker and the listener know what is being discussed and are assisted by references included by the speaker through the symbolism used or the proverbs used. Basically the explanation of the description of the implicature meaning of the figurative sentence type is simple because the speaker has supplied a clear reference through the meaning of the proverb as well as the nature or condition of the symbolic element used. If the speaker uses a proverb in an implicature utterance then the speaker needs to explain the meaning of the proverb first and then relate it to the context. However, if the speaker uses an element of symbolism or metaphor, the listener needs to identify words that can be referenced and linked to the context of the utterance. Each figurative element in the implicature utterance is seen to contain its own meaning and the analysis of Relevance Theory can describe the meaning of the implicature utterance of the figurative sentence as a whole. Clearly, through the analysis conducted the context plays an important role in understanding the meaning of implicature. 


\section{Corresponding Author}

Norhidayu Hasan

Department of Malay Language Faculty Of Modern Language And Communication Universiti Putra Malaysia, Malaysia

Email: hidayuhasan92@gmail.com

\section{Reference}

Ahmad, A., \& Jalaluddin, N. H. (2013). Implikatur Dalam Kes "Pembunuhan Noritta": Analisis Teori Relevans. Jurnal Bahasa , 13 (1), 28-38.

Ahmad, S. (2006). Setitis Embun Semarak Api. Selangor: Alaf 21.

Clark, B. (2013). Relevance Theory. New York: Cambridge University Press

Hassan, A. F. M., \& Hamzah, Z. A. Z. (2010). Pengkategorian Peribahasa Melayu

Berdasarkan Aspek Nilai Dan Pemikiran: Satu Analisis Pragmatik. Retrieved December 10, 2012, From Http://Sastra.Um.Ac.Id/Wpcontent/ Uploads/2010/01

Ismail, G., \& Mat, A. C. (2008). Makna Implikatur Dalam Novel Sasterawan Negara Arena Wati. Seminar Antarabangsa Linguistik Dan Pembudayaan Bahasa Melayu Ke-4, (Pp.178182).

Jalaluddin, N. H. (1992). Implikatur: Satu Aspek Seni Berbahasa Orang Melayu. Dewan Bahasa , 1(3), 676-690.

Jalaluddin, N. H. (2003). Bahasa Dalam Perniagaan. Kuala Lumpur : Dewan Bahasa Dan Pustaka.

Mohamad, Z. (2015). Pengalihan Bahasa Ke Bahasa Melayu: Enam Filem Negara Asean Asal. Seminar Antarabangsa Linguistik Dan Pembudayaan Bahasa Melayu Ix, (Pp. 110-116).

Mohamad, R. S. R., \& Hamzah, Z. A. Z. (2015). Penggunaan Implikatur Sebagai Medium Penjelasan Akidah. Jurnal Linguistik, 19 (2), 1-9.

Peccei, J. S. (1999). Pragmatics. London: Routledge.

Rahim, N. A., \& Hamzah, Z. A. Z. (2008). Kiasan Melayu Sebagai Khazanah Bangsa Melayu. Cendekia: Kumpulan Esei Bahasa, Sastera Dan Budaya Melayu. Fbmk. Upm Serdang. 120-131

Sperber, D., \& Wilson, D. (1999). Relevans Komunikasi Dan Kognisi. (N. H. Jalaluddin, Trans.) Kuala Lumpur: Dewan Bahasa Dan Pustaka.

Sperber, D., \& Wilson, D. (2012). Meaning And Relevance. Cambridge: Cambridge University Press.

Sperber, D., \& Wilson, D. (1986). Relevance Communication And Cognition. Cambridge: Harvard University Press.

Sperber, D., \& Wilson, D. (1998). Pragmatics And Time. In, Relevance Theory Applications And Implications (Pp. 1-22). Amsterdam: John Benjamins Publishing.

Wahab, H. A., \& Kamil, S. M. (2012). Peribahasa Cerminan Budi Bahasa Dan Budaya Bangsa Melayu. Issues In Language Studies, 1 (1), 34-37.

Zainal, M. Z., Musanif, A. M., \& Mydin, A. (2018). Makna Penutur Bagi Ujaran Tak Langsung Dalam Skrip Drama Bahasa Melayu. Jurnal Komunikasi; Malaysian Journal Of Communication, 34(2). Pp. 243-262. 